\title{
Influence of tannins on the protein nutritional quality of food grains
}

\section{By D. HewitT and J. E. Ford, National Institute for Research in Dairying, Shinfield, Reading RG2 $9 A T$}

Tannins are widely present in higher plants, and their presence in some food grains may significantly impair the nutritional quality. Thus for example, in coloured-flowered varieties of field beans (Vicia faba L.) the seeds are rich in condensed tannins and their inclusion in the diet of single-stomached animals has been reported to depress the apparent digestibility of the protein (cf. MartinTanguy et al. 1977; Ronnenkamp, 1977). Similarly in sorghum grain (Sorghum vulgare Pers.) the protein quality in some genotypes is severely limited by the high level of tannins in the testa, and different varieties exhibit wide differences in digestibility that reflect corresponding differences in tannin content.

The presence of tannins complicates the interpretation of amino acid analysis and other compositional information in terms of nutritional quality. We need to take the digestibility of the amino acids into account in our tests, and there are several microbiological assay methods that are very promising for this purpose and are potentially of great value to the plant breeder in guiding the selection of improved food grains. Compared with animal feeding tests they are quick and precise, and much more economical of test materials. Of these methods, the Streptococcus zymogenes assays for available methionine and for relative nutritional value (RNV) have been extensively tested with a variety of high-protein feedstuffs and with rice (Oryza sativa $\mathrm{L}$.), sorghum, barley and field beans (Ford \& Hewitt, I $979 a, b, c)$. Table I shows the results of amino acid digestibility tests with chicks on ten sorghum varieties of graded tannin content, and for comparison the results of microbiological tests and values for dye-binding lysine. The chick assay values for 'average amino acid digestibility' were negatively correlated $(r-0.82$; $P<0.01)$ with tannin content, as were the microbiological assay values for available methionine $(r-0.95 ; P<0.001)$ and for RNV $(r-0.97 ; P<0.001)$. By contrast, the total methionine content varied little between varieties. The same was true for the dye-binding lysine values, which for these samples were clearly a fair measure of the total lysine present. They gave no indication of the differences in lysine digestibility that were found in chick tests.

In similar tests on field beans we compared seed of twenty-two varieties, eleven white-flowered and eleven coloured-flowered. We assayed them with Strep. zymogenes for total and available methionine and RNV, and also for dye-binding lysine and tannin content.

As a group, the white-flowered varieties were richer in available methionine than the coloured $(P<0.00 \mathrm{I})$, though the differences were much less pronounced than those between high- and low-tannin sorghums. Mean values for the two groups were $(\mathrm{g} / \mathrm{kg}$ protein; $\pm \mathrm{SD}) 6.80+0.46$ and $6.27 \pm 0.5 \mathrm{I}$. Mean $\mathrm{RNV}$ ratings also were 
Table 1. Availability of amino acids in sorghum (Sorghum vulgare Pers.) in relation to the tannin content

\begin{tabular}{|c|c|c|c|c|c|c|c|}
\hline \multirow[b]{2}{*}{ Variety } & \multicolumn{2}{|c|}{$\begin{array}{l}\text { Methionine (g/kg } \\
\text { protein) (measured with } \\
\text { Streptococcus } \\
\text { zymogenes) }\end{array}$} & \multirow{2}{*}{$\frac{\text { Available }}{\text { Total }}$} & \multirow[b]{2}{*}{ RNV } & \multirow{2}{*}{$\begin{array}{c}\text { Dye-binding } \\
\text { lysine } † \\
\text { (g/kg } \\
\text { protein) }\end{array}$} & \multirow{2}{*}{$\begin{array}{c}\text { Amino acid } \\
\text { digestibilty } \\
\text { (measured } \\
\text { with } \\
\text { chicks) }\end{array}$} & \multirow{2}{*}{$\begin{array}{c}\text { Tannin } \S \\
(\mathrm{g} / \mathrm{kg})\end{array}$} \\
\hline & Total & Available & & & & & \\
\hline $\begin{array}{l}\mathrm{E}_{57} \\
\mathrm{TE} 66\end{array}$ & $\begin{array}{l}16 \cdot 6 \\
18 \cdot 5\end{array}$ & $\begin{array}{l}15.8 \\
15.5\end{array}$ & $\begin{array}{l}0.95 \\
0.84\end{array}$ & $\begin{array}{l}93 \\
88\end{array}$ & $\begin{array}{l}25.0 \\
23.8\end{array}$ & $\begin{array}{l}0.88 \\
0.91\end{array}$ & $\begin{array}{l}4.9 \\
5.8\end{array}$ \\
\hline $\mathrm{ORO}_{7}$ & 18.4 & $17 \cdot 7$ & 0.96 & 98 & $29 \cdot 1$ & 0.94 & $6 \cdot 9$ \\
\hline AKS 663 & $17 \cdot 0$ & $9 \cdot 7$ & 0.57 & 58 & $29 \cdot 4$ & 0.76 & 17.8 \\
\hline $\operatorname{RS} 617$ & $18 \cdot 5$ & $8 \cdot 5$ & 0.46 & 48 & $25 \cdot 9$ & 0.74 & $16 \cdot 0$ \\
\hline AKS 618 & $16 \cdot 3$ & $6 \cdot 3$ & 0.39 & $3^{1}$ & $22 \cdot 4$ & 0.71 & $23 \cdot 7$ \\
\hline Shoobird & $18 \cdot 1$ & $9 \cdot 2$ & $0.5 \mathrm{I}$ & 49 & $27 \cdot 0$ & 0.86 & tg.8 \\
\hline Savannah & $17 \cdot 7$ & $9 \cdot 9$ & 0.56 & 50 & $28 \cdot 4$ & 0.67 & $20 \cdot 6$ \\
\hline BR 76 & 17.5 & 6.6 & $0 \cdot 3^{8}$ & 37 & $26 \cdot 6$ & 0.66 & $26 \cdot 0$ \\
\hline Ga 615 & $17 \cdot 4$ & $7 \cdot 4$ & 0.43 & 39 & $25 \cdot 2$ & 0.83 & 23.4 \\
\hline $\operatorname{LSD}(P=0.05)$ & I. 3 & I. 4 & - & $5 \cdot 1$ & - & - & $2 \cdot 6$ \\
\hline
\end{tabular}

marginally higher for the white-flowered varieties $(66 \cdot 0 \pm 3.5$ v. $6 \mathrm{I} \cdot 9 \pm 3.8)$, but dye-binding lysine values were the same for both groups.

Beans of the white-flowered varieties contained no tannins, whereas those of the coloured-flowered varieties contained high and variable amounts, which were negatively correlated with the content of available methionine $(r-0.75 ; P<0.01)$. Griffiths \& Jones (1977) similarly found wide variation in tannin content within coloured-flowered varieties, which was highly correlated with the digestibility of the testa by cellulose.

A point that emerged clearly from this comparison was that, with field beans, the influence of the seed tannin on amino acid digestibility was less pronounced than with sorghum grain of similar tannin content. The condensed tannins in both species are chemically akin (Marquardt et al. 1977); and their different biological effects may be related to differences in degree of polymerization.

\section{Influence of polyethyleneglycol on the nutritional availability of methionine in} sorghum and field beans

Both in sorghum and field beans, tannin content is simply inherited and is controlled by only one or two major genes. It is no difficult matter for the plant breeder to eliminate the tannin factors, but in doing so he may lose important agronomic advantages of the high-tannin lines. A practical alternative might be to inactivate the tannins in the existing high-tannin varieties, and there are several 
ways in which this can be done. One way is to add absorbents to which the tannins bind more strongly than to protein. Polyvinylpyrollidone (PVP) and various derivatives of polyethyleneglycol (PEG) have been used for this purpose to protect plant enzymes during extraction from higher plants (Jones \& Hulme, I 96 I ; Loomis \& Battaile, 1964; Boudet, I965), and Rayudu et al. (1970) showed that this property of binding tannins is operative in vivo. They found that PVP and Tween 80 (polyoxyethylene sorbitan mono-oleate) reduced the growth-depressing effect of tannic acid in chicks.

Ford (1977) and Ford \& Hewitt (1979b) examined in vitro the effects of PEG 4000 on protein nutritional quality and amino acid availability in seventeen varieties of sorghum and twenty of field beans. The results for sorghum are shown in Table 2. The RNV values fell into two distinct groups, averaging 86.8 (range 79-92) for six low-tannin varieties and $4 \mathrm{I} \cdot \mathrm{O}$ (range 30-53) for eleven varieties of medium- to high-tannin content. The same was true for the ratio available:total

Table 2. Influence of polyethyleneglycol (PEG 4000) on the relative nutritional value (RNV)* and availability of the methionine of grain of seventeen varieties of sorghum (Sorghum vulgare Pers.) in relation to the tannin content

(Values in parentheses represent the 'available' values as a proportion of the corresponding 'total')

\begin{tabular}{|c|c|c|c|c|c|c|}
\hline \multirow[b]{3}{*}{$\begin{array}{l}\text { Sorghum } \\
\text { variety }\end{array}$} & \multirow[b]{3}{*}{$\begin{array}{l}\text { Tannin } \\
\text { index } \dagger\end{array}$} & & & \multicolumn{3}{|c|}{ Methionine ( $\mathrm{g} / \mathrm{kg}$ protein) } \\
\hline & & \multicolumn{2}{|c|}{ RNV } & & \multicolumn{2}{|c|}{ Available } \\
\hline & & $\begin{array}{l}-\mathrm{PEG} \\
4000\end{array}$ & $\begin{array}{c}+ \text { PEG } \\
4000\end{array}$ & Total & $\begin{array}{r}- \text { PEG } \\
4000\end{array}$ & $\begin{array}{r}+ \text { PEG } \\
4000\end{array}$ \\
\hline $\operatorname{SSK}_{52}$ & 0.22 & 83 & 83 & 13.9 & $15 \cdot 8(1 \cdot 14)$ & $16 \cdot 5(1 \cdot 19)$ \\
\hline$E_{57}$ & 0.24 & 91 & 95 & $16 \cdot 6$ & $17 \cdot 3(1 \cdot 04)$ & $18.0(1.08)$ \\
\hline $\mathrm{ORO}_{7}$ & 0.28 & 92 & 96 & 18.4 & $18.9(1.03)$ & $20 \cdot 1(1.09)$ \\
\hline TE 66 & 0.29 & 79 & 84 & $18 \cdot 5$ & $15.7(0.85)$ & $16.6(0.90)$ \\
\hline RS 671 & 0.34 & 86 & 86 & 15.8 & $15.7(0.99)$ & $15.9(1.01)$ \\
\hline $74^{-115}$ & 0.41 & 90 & 89 & $16 \cdot 6$ & $18 \cdot 4(1 \cdot 11)$ & $18 \cdot 6(1 \cdot 12)$ \\
\hline RS 617 & 0.96 & 44 & 79 & $18 \cdot 4$ & $9.0(0.49)$ & $15.8(0.86)$ \\
\hline Savannah & I. 04 & 46 & 82 & $17 \cdot 7$ & $9.9(0.56)$ & $17.5(0.99)$ \\
\hline Shoobird & 1.08 & 45 & $8 I$ & 18.1 & $10.4(0.57)$ & $16.8(0.93)$ \\
\hline AKS $66_{3}$ & $1 \cdot 10$ & 53 & 80 & $17 \cdot 0$ & $10.5(0.62)$ & $15.5(0.91)$ \\
\hline $\mathrm{Ga} 615$ & I. 16 & 35 & 71 & $17 \cdot 4$ & $8.8(0.5 \mathrm{I})$ & $16.0(0.92)$ \\
\hline AKS 618 & $1 \cdot 22$ & 30 & $5^{8}$ & $16 \cdot 3$ & $8.1(0.50)$ & $12.8(0.79)$ \\
\hline $\mathrm{BR} 76$ & $1 \cdot 23$ & 33 & 77 & 17.5 & $6.7\left(0.3^{8}\right)$ & I6. I $(0.92)$ \\
\hline $74^{-123}$ & I. 30 & 53 & 87 & 16.8 & II.O $(0.65)$ & $18.5(1 \cdot 10)$ \\
\hline BR 54 & 1.80 & $3^{8}$ & 84 & $18 \cdot 0$ & $8.4(0.47)$ & $16.0(0.89)$ \\
\hline $\mathrm{X}_{3101}$ & $1 \cdot 90$ & 39 & $7^{6}$ & $14 \cdot 5$ & $8.3(0.57)$ & $15.5(1.07)$ \\
\hline $74-118$ & $1 \cdot 90$ & 35 & 83 & $16 \cdot 0$ & $7 \cdot 2(0 \cdot 45)$ & $17 \cdot 2(1.08)$ \\
\hline $\operatorname{LsD}(P-0.05)$ & $0 \cdot 18$ & & & $\mathrm{I} \cdot 3$ & & \\
\hline
\end{tabular}


methionine, which averaged I $03(0.85-I \cdot I 4)$ for the low-tannin varieties and 0.52 $\left(0.3^{8-0.65)}\right.$ for the remainder. Addition of PEG 4000 to the test samples changed this picture, increasing the values for the high-tannin varieties to equal those for the tannin-free.

Table 3 shows the influence of PEG 4000 treatment of field beans on the available methionine content, as measured microbiologically. PEG 4000 treatment of ten white-flowered varieties (Table $3(a)$ ) did not affect the mean value, whereas with ten coloured-flowered varieties it gave a small increase (approximately $5 \%$ ).

For eight of the samples, two 'white' and six 'coloured', available methionine was measured again in two independent assays (Table $3(b)$ ). With the 'coloured' varieties, PEG 4000 treatment gave a small but consistent increase of about $6 \%$, which for the group was statistically significant.

\section{Biological tests with chicks and rats}

The foregoing results of in vitro assays were checked in biological tests on some of the same test samples (Ford \& Hewitt, 1979c). True digestibility, biological value (BV) and net protein utilization (NPU) were measured by the nitrogen balance

Table 3. Influence of polyethyleneglycol (PEG 4000) on results for available methionine in white- and coloured-flowered varieties of field beans (Vicia faba $L$.)

$$
\overbrace{- \text { PEG } 4000+\text { PEG } 4000}^{\text {Available methionine (g/kg protein) }} \text { Change (\%) }
$$

(a) Mean value for ten white- and ten coloured-flowered varieties

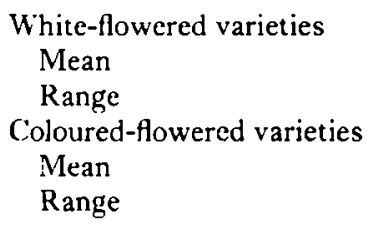

$$
\begin{array}{ccc}
6 \cdot 47 & 6 \cdot 48 & 0.24 \\
5 \cdot 57-7 \cdot 23 & 5 \cdot 64-7 \cdot 13 & -2 \cdot 3 \text { 1 to }+4 \cdot 28 \\
6 \cdot 20 & 0 \cdot 51 & 4 \cdot 95 \\
5 \cdot 84-6 \cdot 76 & 6 \cdot 11-7 \cdot 00 & -0.59 \text { to }+9 \cdot 42
\end{array}
$$

(b) Individual values for two white- and six coloured-flowered varieties

$\begin{array}{lcccc}\text { Variety } & \text { Tannin index } † & \text { - PEG } 4000 & + \text { PEG } 4000 & \text { Change }(\%) \\ \text { Threefold White } & 0.050 & 6.90 & 6.94 & +0.5 \\ \text { Compacta } & 0.014 & 6.92 & 6.83 & -1.2 \\ \text { Blaze } & 0.835 & 5.88 & 6.27 & +6.5 \\ \text { Bead } & 0.835 & 5.90 & 6.18 & +4.9 \\ \text { Throws MS } & 0.908 & 5.92 & 6.28 & +6.1 \\ \text { Bulldog } & 0.710 & 6.32 & 6.70 & +6.0 \\ \text { Compacta brown } & 0.710 & 6.24 & 6.68 & +7.0 \\ \text { Felix } & 0.688 & 6.66 & 7.06 & +6.0 \\ \text { LSD }(P=0.05) & & & \end{array}$

LSD, least significant difference.

- Measured with Streptococcus zymogenes as described by Ford \& Hewitt (1979a).

Measured as described by Ford \& Hewitt ( $1979 a$ ). 
procedure with rats, and true $\mathbf{N}$ and amino acid digestibilities by the ileal analysis procedure with chickens (Varnish \& Carpenter, 1975).

Sorghums. The results given in Table 4 are typical of those obtained for hightannin sorghums. In rat tests, the protein was poorly digested. Supplementation of the diets with PEG 4000 gave a large improvement, which was offset by an apparent decrease in BV. However, this fall was in a sense spurious, because estimates of BV may be widely different at different levels of protein intake (Osborne et al. 1919; Mitchell, 1923-4); and in testing high-tannin sorghums in presence and absence of PEG 4000 we were in effect comparing widely different levels of intake of a lysine-deficient protein. With chickens, $\mathrm{N}$ digestibility of hightannin sorghum was even lower and was similarly improved with PEG 4000 . With low-tannin sorghums protein digestibility was high $(0.97-1.00)$ and unaffected by addition of PEG 4000.

Eggum \& Christensen (1975) found with rats that addition of 'tannin' to soyabean diets depressed the digestibility of the protein. The tannin also reduced the digestibility of individual amino acids but to differing degrees. In our experience also, the tannins had a distinct differential effect on digestibility of different amino acids. Digestibility of proline was markedly low, as reported by Eggum \& Christensen (1975). We found the same for cystine, which in one high-tannin sorghum was completely recovered, undigested, in the lower ileum contents. On addition of PEG 4000 to this diet the digestibility of cystine was increased from 0.01 to 0.74 .

Field beans. Biological tests were done on the field bean varieties Threefold White and Throws MS, representing tannin-free, white-flowered and high-tannin, 'coloured' varieties respectively. The results are given in Tables 5 and 6.

Table 5 shows the results of two experiments with rats, both of which indicated that $\mathrm{N}$-digestibility in Throws MS was marginally lower than in Threefold White,

Table 4. Influence of polyethylene glycol (PEG 4000) on the nutritional quality of high-tannin sorghums (Sorghum vulgare Pers.), as measured with rats using the nitrogen-balance procedure and with chickens using the ileal digestibility method

\begin{tabular}{|c|c|c|c|c|c|}
\hline \multirow[t]{2}{*}{ Sorghum } & & \multicolumn{3}{|c|}{ PEG 4000 added (g/g protein) } & \multirow{2}{*}{$\begin{array}{c}\text { LSD } \\
(P=0.05)\end{array}$} \\
\hline & & 0 & 0.1 & I. 0 & \\
\hline & & \multicolumn{3}{|c|}{ Rat assay } & \\
\hline \multirow{4}{*}{$\mathrm{X}_{3}$ IOI } & Digestibility & 0.53 & 0.92 & 0.99 & 0.07 \\
\hline & BV & 0.77 & 0.59 & $0.5^{8}$ & $0.1 \mathrm{I}$ \\
\hline & NPU & 0.42 & 0.55 & 0.57 & O.I I \\
\hline & Digestibility & 0.80 & 0.88 & - & 0.01 \\
\hline \multirow[t]{3}{*}{ 'Brown' } & BV & 0.74 & 0.68 & & 0.03 \\
\hline & NPU & 0.59 & 060 & -- & 0.03 \\
\hline & \multicolumn{4}{|c|}{ Chicken assay } & \\
\hline $\mathrm{X}_{3}$ IOI & Digestibility & 0.44 & 0.90 & 0.94 & 0.10 \\
\hline
\end{tabular}

LSD, least significant difference. 
Table 5. Influence of polyethylene glycol (PEG 4000) on true digestibility, biological value (BV) and net utilization of the protein (NPU) in low-tannin (Threefold) and in high-tannin (Throws MS) field beans (Vicia faba $L$.), measured using the rat nitrogen-balance procedure, and diets with and without supplementary methionine

$\begin{array}{llllll}\begin{array}{c}\text { PEG 4000 added } \\ \text { (g/g protein) }\end{array} & \overbrace{0}^{0.1} & \overbrace{0}^{0.1} & \begin{array}{c}0.1 \\ \text { (No supplementary methionine in test diets) }\end{array} \\ \text { Digestibility } & 0.936 & 0.927 & 0.905 & 0.930 & 0.034 \\ \text { BV } & 0.251 & 0.257 & 0.230 & 0.281 & 0.13 \\ \text { NPU } & 0.238 & 0.239 & 0.210 & 0.263 & 0.12\end{array}$

\section{Digestibility}

BV

NPU

(Test diets contained $2.5 \mathrm{~g}$ supplementary methionine $/ \mathrm{kg}$ )

$\begin{array}{lllll}0.937 & 0.938 & 0.906 & 0.925 & 0.026 \\ 0.766 & 0.759 & 0.749 & 0.749 & 0.04 \\ 0.718 & 0.712 & 0.679 & 0.693 & 0.06\end{array}$

LSD, least significant difference.

Table 6. Influence of polyethylene glycol (PEG 4000) on true digestibility of the protein in low-tannin (Threefold) and high-tannin.(Throws MS) field beans (Vicia faba $L$.), measured using the chick ileal analysis procedure

PEG 4000 added
(g/g protein)
Expt
1
2
3
4
Mean

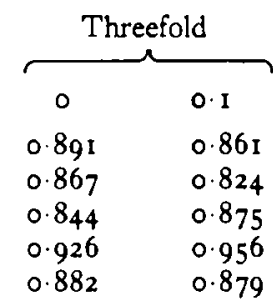

$\overbrace{0}^{\text {Throws . MS }} \begin{array}{ll}0.1 \\ 0.829 & 0.884 \\ 0.807 & 0.834 \\ 0.843 & 0.866 \\ 0.867 & 0.917 \\ 0.837 & 0.875\end{array}$

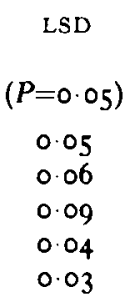

ISD, least significant difference.

and was increased in the presence of PEG 4000. Analysis of variance, however, showed no significant difference between the test diets. Table 6 shows the results of four experiments with chickens. As in the rat tests, inclusion of PEG 4000 in the diets gave a small but consistent improvement in N-digestibility with Throws MS. Analysis of the combined results of the four tests showed that the improvement with Throws MS was significant, and that with PEG 4000 its digestibility was similar to that of Threefold White.

\section{Growth trials with chicks}

To assess the significance of these findings in practical nutrition we have done a series of growth tests with male broiler chicks. In most instances the ground seeds were tested in diets that were slightly suboptimal in protein content $(180 \mathrm{~g} / \mathrm{kg})$ but 
adequate in other nutrients. In a first experiment with sorghum, pure amino acids were included so that requirements for individual essential amino acids were fully met. The major consituents of the basal diet were present in the following amounts (g/kg): maize meal 420 , sorghum 300 , soya-bean meal 150 , fishmeal 80 . PEG 4000 was added where indicated at the rate of $5 \mathrm{~g} / \mathrm{kg}$. The diets were granulated before feeding. In absence of PEG 4000 the chicks on low-tannin 'yellow' sorghum gained more weight with greater efficiency than those on high-tannin 'brown' sorghum, though the difference in FCE was not significant (Table 7). Addition of PEG 4000 to 'yellow' sorghum increased gain and FCE slightly, the effect on FCE bordering on statistical significance. The effects of PEG 4000 on weight gain and FCE with 'brown' sorghum were large and clearly significant. Such an increase in FCE (5\%) also appeared to be cost effective. Using costs which were then current (December, r978) Ford \& Hewitt (1979c) calculated that with broiler diets at $f_{1} 65 /$ tonne and PEG 4000 at $f_{5} 65 /$ tonne the saving in cost of food would amount to $£_{4} .60 /$ tonne ( $f 8.00 /$ tonne less $£_{3} \cdot 4^{\circ}$, the cost of PEG 4000 if added at $6 \mathrm{~kg} /$ tonne).

The results for amino acid digestibilities referred to previously (p. II) suggested that sorghum tannins had a specific effect on cystine and this aspect was further investigated by feeding diets with and without the addition of cystine. The experiment design was a $2 \times 2 \times 2$ factorial with factors cystine addition, PEG 4000 addition and type of sorghum.

With diets containing low-tannin RS69o there were no significant effects though PEG 4000 gave a small improvement (Table 8) as it did with 'yellow' sorghum (Table 7). Surprisingly, though the basal diets were calculated to be deficient in sulphur amino acids, cystine was without effect. With the diets containing hightannin BR 54 the average effects of PEG 4000 and of cystine were both significant but as in the previous experiment, the interactions between PEG 4000 and type of sorghum were not significant. Even so, the effects of PEG 4000 and cystine were somewhat greater with the high-tannin sorghum and the results are consistent with the indication (p. I 1 ) that as well as generally affecting protein digestion the tannins may specifically affect cystine.

Table 7. Effect of polyethylene glycol (PEG 4000; $5 \mathrm{~g} / \mathrm{kg}$ diet) on weight gain $(\mathrm{g} / \mathrm{d})$ and food conversion efficiency (FCE:weight gain $(g) /$ food eaten $(g)$ ) of chicks given low-tannin ('yellow') and high-tannin ('brown') sorghums (Sorghum vulgare Pers.)

\begin{tabular}{|c|c|c|c|}
\hline Sorghum & & Weight gain & FCE \\
\hline 'Yellow' & $\begin{array}{l}\text {-PEG } 4000 \\
+ \text { PEG } 4000\end{array}$ & $\begin{array}{l}21 \cdot 2 \\
22 \cdot 0\end{array}$ & $\begin{array}{l}0.6 c \\
0.62\end{array}$ \\
\hline 'Brown' & $\begin{array}{l}- \text { PEG }_{4000} \\
+ \text { PEG }_{4000}\end{array}$ & $\begin{array}{l}20 \cdot 0 \\
2 I \cdot 4\end{array}$ & $\begin{array}{l}0.5 \\
0.6\end{array}$ \\
\hline & $\operatorname{LSD}(P=0.05)$ & I. 0 & 0.0 \\
\hline
\end{tabular}

LSD, least significant difference. 
Table 8. Effect of polyethylene glycol (PEG 4000; $6 \mathrm{~g} / \mathrm{kg} \mathrm{diet)} \mathrm{on} \mathrm{weight} \mathrm{gain}$ $(g / d)$ and food conversion efficiency (FCE: weight gain $(g) /$ food eaten $(g)$ ) of chicks given low-tannin $(R S 690)$ and high-tannin $\left(B R{ }_{54}\right)$ sorghums (Sorghum vulgare Pers.) with and without supplementary cystine $(\mathrm{I} \cdot 9 \mathrm{~g} / \mathrm{kg})$

Sorghum

\begin{tabular}{|c|c|}
\hline RS69o & $\left\{\begin{array}{l}\text {-PEG } 4000 \\
+ \text { PEG } 4000\end{array}\right.$ \\
\hline BR 54 & $\left\{\begin{array}{l}\text {-PEG } 4000 \\
+ \text { PEG } 4000\end{array}\right.$ \\
\hline
\end{tabular}

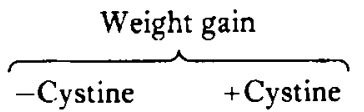

$19 \cdot 8$

$20 \cdot 9$

$18 \cdot 5$

$20 \cdot 8$

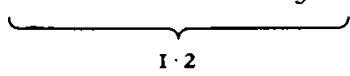

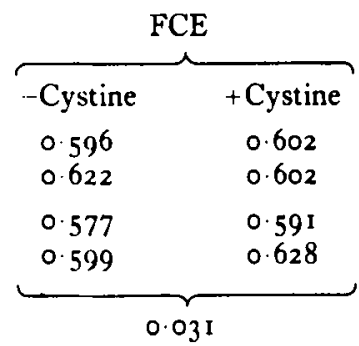

LSD, least significant difference.

Table 9. Effect of polyethylene glycol (PEG 4000; $12 \mathrm{~g} / \mathrm{kg}$ diet) on weight gain $(g / d)$ and food conversion efficiency (FCE:weight gain $(g) /$ food eaten $(g)$ ) of chicks given low-tannin (Threefold White) and high-tannin (Throws MS) field beans (Vicia faba $L$.) as sole source of dietary protein

\begin{tabular}{|c|c|c|c|}
\hline Field bean & & Weight gain & FCE \\
\hline $\begin{array}{c}\text { Threefold } \\
\text { White }\end{array}$ & $\left\{\begin{array}{l}- \text { PEG } 4000 \\
+ \text { PEG } 4000\end{array}\right.$ & $\begin{array}{l}I \cdot 07 \\
I \cdot 13\end{array}$ & $\begin{array}{l}0.097 \\
0.008\end{array}$ \\
\hline Throws MS & $\left\{\begin{array}{l}-\mathrm{PEG}_{4000} \\
+ \text { PEG } 4000\end{array}\right.$ & $\begin{array}{l}0.44 \\
1.42\end{array}$ & $\begin{array}{l}0.043 \\
0.114\end{array}$ \\
\hline & $\operatorname{LSD}(P=0.05)$ & 0.56 & $0.04 \mathrm{I}$ \\
\hline
\end{tabular}

LSD, least significant difference.

In all the previously mentioned microbiological and biological tests, the tannins in field beans had less effect on nutritional value than those in sorghum. In further growth tests Threefold White and Throws MS field beans were given as the sole source of protein ( $120 \mathrm{~g}$ protein $/ \mathrm{kg}$ ) in an otherwise semi-purified diet. The diets were low in protein and acutely deficient in sulphur amino acids and the chicks grew very poorly (Table 9). Under these conditions PEG 4000 supplementation of Throws MS gave a marked increase in weight gain and FCE whereas with Threefold White it was without effect. The interactions between variety and PEG 4000 were significant $(P<0.05)$; indeed, highest performance was recorded with Throws MS when supplemented with PEG 4000.

The same two varieties of field beans were next tested in practical diets with I 80 g protein $/ \mathrm{kg}$, containing $(\mathrm{g} / \mathrm{kg})$ : field beans 460 , maize meal $4 \mathrm{I} 9$, soya-bean meal 20 , fishmeal 15 . The design was a $2 \times 2 \times 2$ factorial with factors methionine addition, PEG 4000 addition and variety of field bean. 
There was a large response to methionine addition with both varieties (Table 10). The PEG 4000 supplement improved performance a little, the effect on growth arising in part from increased food intake so that the effect on FCE though evident was small.

The possibility was considered that the potency of the tannins in the sample of Throws MS used in this last experiment might have declined because it had been stored for over a year. We therefore obtained, through the kind offices of $\mathrm{Dr} \mathrm{D}$. A. Bond, freshly harvested samples of white- and coloured-flowered varieties and tested them within 4 months of receipt. The formulations were similar to those used in the previous experiment with supplemental methionine. There was very little difference between the varieties, though in the absence of PEG 4000 FCE was less for the high-tannin varieties, Beagle and Minica (Table II). Growth was

Table 10. Effect of polyethylene glycol (PEG 4000; $24 \mathrm{~g} / \mathrm{kg}$ diet) on weight gain $(\mathrm{g} / \mathrm{d})$ and food conversion efficiency (FCE:weight gain (g)/food eaten $(\mathrm{g})$ ) of chicks given low-tannin (Threefold White) and high-tannin (Throws MS) field beans (Vicia faba $L$.) with and without a supplement of methionine $(3 \mathrm{~g} / \mathrm{kg})$

\begin{tabular}{|c|c|c|c|c|c|}
\hline \multirow[b]{2}{*}{ Field bean } & & \multicolumn{2}{|c|}{ Weight gain } & \multicolumn{2}{|c|}{ FCE } \\
\hline & & Methionine & + Methionine & -Methionine & + Methionine \\
\hline $\begin{array}{l}\text { Threefold } \\
\text { White }\end{array}$ & $\left\{\begin{array}{l}\text { - PEG } 4000 \\
+ \text { PEG } 4000\end{array}\right.$ & $\begin{array}{r}9.5 \\
11.7\end{array}$ & $\begin{array}{l}19 \cdot 9 \\
22 \cdot 6\end{array}$ & $\begin{array}{l}0.361 \\
0.394\end{array}$ & $\begin{array}{l}0.559 \\
0.562\end{array}$ \\
\hline \multirow[t]{2}{*}{ Throws MS } & $\left\{\begin{array}{l}- \text { PEG }_{4000} \\
+ \text { PEG } 4000\end{array}\right.$ & $\begin{array}{r}9 \cdot 4 \\
10 \cdot 3\end{array}$ & $\begin{array}{l}18 \cdot 7 \\
21 \cdot 7\end{array}$ & $\begin{array}{l}0.355 \\
0.365\end{array}$ & $\begin{array}{l}0.530 \\
0.562\end{array}$ \\
\hline & $\operatorname{LSD}(P \div 0.05)$ & \multicolumn{2}{|c|}{$I \cdot 2$} & \multicolumn{2}{|c|}{0.032} \\
\hline
\end{tabular}

Table I I. Effect of polyethylene glycol (PEG $4000 ; 24 \mathrm{~g} / \mathrm{kg}$ diet) on weight gain $(g / d)$ and food conversion efficiency (FCE:weight gain $(g) /$ food eaten $(g))$ of chicks given low-tannin (Polar and Rowena) and high-tannin (Beagle and Minica) field beans (Vicia faba $L$.)

\begin{tabular}{|c|c|c|c|}
\hline Field bean & & Weight gain & FCE \\
\hline Polar & $\left\{\begin{array}{l}- \text { PEG }_{4000} \\
+ \text { PEG } 4000\end{array}\right.$ & $\begin{array}{l}25.9 \\
249\end{array}$ & $\begin{array}{l}0.620 \\
0.592\end{array}$ \\
\hline Rowena & $\left\{\begin{array}{l}- \text { PEG }_{4} 000 \\
+ \text { PEG }_{4} 000\end{array}\right.$ & $\begin{array}{l}25 \cdot 1 \\
25 \cdot 6\end{array}$ & $\begin{array}{l}0.630 \\
0.616\end{array}$ \\
\hline Beagle & $\left\{\begin{array}{l}- \text { PEG }_{4} 000 \\
+ \text { PEG } 4000\end{array}\right.$ & $\begin{array}{l}23 \cdot 9 \\
24 \cdot 8\end{array}$ & $\begin{array}{l}0.603 \\
0.594\end{array}$ \\
\hline Minica & $\left\{\begin{array}{l}\text {-PEG } 4000 \\
+ \text { PEG }_{4} 000\end{array}\right.$ & $\begin{array}{l}25.0 \\
25.8\end{array}$ & $\begin{array}{l}0.610 \\
0.629\end{array}$ \\
\hline & $\operatorname{LSD}(P=0.05)$ & $I \cdot 4$ & 0.018 \\
\hline
\end{tabular}


slightly improved by addition of PEG 4000 to diets containing these two varieties but generally the effects of PEG 4000 were small and inconsistent.

In contrast to our findings Martin-Tanguy et al. (1977) reported larger differences between low- and high-tannin varieties of field beans. In tests with chicks given mixed diets they found a range of apparent digestibilities for protein of $0.71-0.89$ which correlated negatively with iannin content. And in trials with laying hens and Muscovy ducklings they found considerable differences between varieties of field beans which also correlated with tannin content. With rats, Moseley \& Griffiths (1979) showed that testa from the coloured-flowered field bean variety Dylan, when included in the diet at $100 \mathrm{~g} / \mathrm{kg}$, reduced live-weight gain, food efficiency and PER, principally by its effect on $\mathrm{N}$ digestibility, whereas testa from the low-tannin variety Threefold White had no such effect. The diets contained $300 \mathrm{~g}$ bean cotyledon $/ \mathrm{kg}$ as well as the testa and digestibilities of $\mathrm{N}$ were 0.85 for Threefold White testa and 0.75 for 'Dylan'. The difference in digestibility was greater than we found between low- and high-tannin varieties, probably because the testa were included at twice the concentration that we used in our test diets, which were based on whole beans.

\section{Conclusions}

Over all, our results indicate that the tannins in coloured-flowered varieties of field beans cause a small but significant depression of protein nutritional quality which may be reversed by addition of PEG 4000 to the diet. With sorghum the effect of high-tannin content in depressing the nutritional quality was clear and unequivocal, as was the effect of PEG 4000 in preventing this depression. The use of PEG 4000 seems to offer a simple and cost-effective means of improving the nutritional quality and commercial value of such high-tannin sorghum grains.

\section{REFERENCES}

Boudet, A. (1965). C. R. hebd. Séanc. Acad. Sci., Paris 261, 214.

Eggum, B. O. \& Christensen, K. D. (1975). In Breeding for Seed Protein Improvement Using Nuclear Techniques (Proc. Res. Co-ord. Meeting, Ibadan, 1973), p. 135. Vienna: International Atomic Energy Authority.

Ford, J. E. ( 1977). Proc. Nutr. Soc. 36, 125 A.

Ford, J. E. \& Hewitt, I). (I979a). Br. F. Nutr. 4I, 34 I.

Ford, J. E. \& Hewitt, D. (1979b). Br. F. Nutr. 42, 317 .

Ford, J. E. \& Hewitt, I). (I979c). Br. F. Nutr. 42, 325 .

Griffiths, I. W. \& Jones, D. I. H. (1 977). J. Sci. Fd Agric. 28, 983.

Hurrell, R. F. \& Carpenter, K. J. (1976). Proc. Nutr. Soc. 35, 23 A.

Jones, J. D. \& Hulme, A. C. (1961). Nature, Lond. 191, 370.

Loomis, W. D. \& Battaile, J. (1964). Plant Physiol. 39, Supp., iz.

Marquardt, R. R., Ward, A. T., Campbell, I. D. \& Cansfield, P. E. (1977). F. Nutr. 107, 131 3.

Martin-Tanguy, J., Guillaume, J. \& Kossa, A. (1977). F. Sci. Fd Agric. 28, 757.

Maxson, E. D. \& Rooney, L. W. (1972). Cereal Chem. 49, 7 r9.

Mitchell, H. H. (1923-4). J. biol. Chem. 58, 905.

Moseley, G. \& Griffiths, D. W. (1979). F. Sci. Fd Agric. 30, 772.

Nelson, T. S., Stephenson, E. L., Burgos, A., Floyd, J. \& York, J. O. (1975). Poult. Sci. 54, 1620. 
Osborne, T. B., Mendel, L. B. \& Ferry, E. L. (1919). F. biol. Chem. 37, 223.

Rayudu, G. V. N., Kadirvel, R., Vohra, P. \& Kratzer, F. H. (1970). Poult. Sci. 49, r323.

Ronnenkamp, R. R. (1977). The effect of tannins on nutritional quality of dry beans, Phoseolus vulgaris $\mathrm{L}$. PhD Thesis, Purdue University, West Lafayette, Ind., USA.

Varnish, S. A. \& Carpenter, K. J. (1975). Br. F. Nutr. 34, 339. 